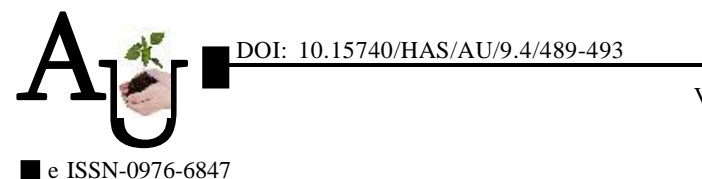

e ISSN-0976-6847

Research Article

\title{
Impact of Swarnajayanti Gram Swarozgar Yojana with reference to credit utilization for agriculture among the beneficiaries of Rewa district
}

\author{
N.S. KHEDKAR AND S.S. DHAKAD
}

Article Chronicle :

SUMMARY : The Swarnajayanti Gram Swarozgar Yojana (SGSY) is a major-self-employment and credit cum Received :

13.08.2014;

Revised :

01.09.2014;

Accepted :

15.09.2014

subsidy programme under implementation in the country and the scheme has been funded by the centre and the states govt. in the ratio of 75:25, respectively. The present study was conducted during 2006-07 in Rewa block in Rewa district Madhya Pradesh. The total sample for the study consisted of 120 beneficiaries of marginal and small farmers. The study concluded that the association of attributes like education, land holding, size of family, social participation, personal experience of credit utilization pattern, attitude towards credit utilization under SGSY programme, economic motivation, contact with development agencies and mass media was observed highly significant with increase in annual income of the beneficiaries. The co-efficient of multiple determinations (R2) indicated that only 83.03 per cent of variation in the annual income increased of the respondents could be explained due to 10 independent variables.

How to cite this article : Khedkar, N.S. and Dhakad, S.S. (2014). Impact of Swarnajayanti Gram Swarozgar Yojana with reference to credit utilization for agriculture among the beneficiaries of Rewa district. Agric. Update, 9(4): 489-

KeY Words : 493.

Swarnajayanti Gram

Swarozgar

Yojana,Agrilculture, BPL, Poverty alleviation, Self help group 